Rocznik Andragogiczny

AMDRAGOGY YEABBOOK 2015

DOl: hitp://dx.doi.org/10.12775//RA.2015.027

\title{
Anna Jaroszewska, Nauczanie języków obcych seniorów w Pol- sce, Wydawnictwo Impuls, Kraków 2013, ss. 546.
}

Potrzeba analizy procesów nauczania i uczenia się osób starszych jest niezwykle istotną kwestią poruszaną aktualnie przez środowisko andragogów i gerontologów społecznych. Za sprawą zmiany praktyk uczenia się dorosłych w Polsce - przejawiających się m.in. w postaci intensywnego rozwoju ilościowego uniwersytetów trzeciego wieku (UTW), klubów seniora i proseniorskich organizacji pozarządowych - wzrasta konieczność reorientacji praktycznego spojrzenia na mechanizmy uczenia się i nauczania osób starszych.

Recenzowana publikacja składa się z pięciu części. W pierwszej z nich scharakteryzowane zostało nauczanie i uczenie się $\mathrm{w}$ pryzmacie wielowątkowych uwarunkowań procesu edukacyjnego. Autorka, analizując zagadnienie edukacji w zakresie języków obcych, celowo używa pojęć uczenie się i nauczanie, które nierozerwalnie ze sobą powiązane, tworzą złożony system czynników zależnych i niezależnych od osoby nabywającej nowe kompetencje. Anna Jaroszewska jako językoznawca nie tylko opisuje dydaktyczne i glottodydaktyczne przesłanki procesu nabywania umiejętności językowych, lecz także sięga do ważnych wątków (demograficznych, społecznych i kulturowych) warunkujących psychospołeczne funkcjonowanie osób starszych. Projektując proces badawczy, autorka zauważyła, że w polskiej przestrzeni badawczej można dostrzec brak publikacji odnoszących się do opisywanego zagadnienia. Czynnik ten sprawił, że konieczność aktualnego i szerokiego spojrzenia na omawianą tematykę stał się jeszcze bardziej zasadny. Z książki Jaroszewskiej można wysunąć wniosek, że polska „geragogika filologiczna" na tle innych krajów europejskich jawi się jako młoda, nierozwinięta subdyscyplina, pomimo faktu iż badania w tym obszarze zostały zapoczątkowane w krajach zachodnich już w latach 70. XX w.

W drugim rozdziale autorka prezentuje podstawy procesów biologicznych, a także psychologicznych, które tworzą sieć uwarunkowań rzutujących na podejmowanie aktywności edukacyjne przez osoby starsze. Rozdział 
ten jest szczególnie ważny dla lektorów realizujących kursy w UTW oraz $\mathrm{w}$ podobnych instytucjach, lecz nieposiadających wiedzy na temat procesów poznawczych najstarszych uczniów. Podsumowanie rozdziału składa się z rozbudowanej charakterystyki ucznia w późnej dorosłości wraz z pogrupowanym wykazem cech wpływających na postępy i ograniczenia w uczeniu się języków obcych.

Trzeci rozdział stanowi złożoną analizę uwarunkowań tworzących podstawy dla systemu kształcenia osób starszych. Autorka w tekście odnosi się do: założeń polityki Unii Europejskiej (UE), konsekwencji związanych ze starzeniem się społeczeństwa, międzykulturowości oraz wielojęzyczności jako jednego z wyznaczników globalizacji, strategii i koncepcji uczenia się przez całe życie, polityki UE wobec osób starszych, typologii kompetencji kluczowych oraz ukazania polskich rozwiązań i założeń systemu kształcenia językowego dedykowanego seniorom. Ostatni z rozdziałów można polecić w szczególności komparatystom edukacyjnym.

Czwarty rozdział należy traktować jako zasadniczą część książki. Zostały w nim zaprezentowane cele badań związane z uzyskaniem aktualnych informacji na temat procesu nauczania i uczenia się języków obcych przez seniorów na przykładzie polskich rozwiązań dydaktycznych. W rozdziale tym omówiono teoretyczne podstawy badań oraz budowę narzędzi. Publikacja powstała na podstawie analizy bogatego zasobu literatury polskiej i zagranicznej. Autorka, projektując proces badawczy, zastosowała strategię triangulacji metod. Narzędzia badawcze, wyniki badań ilościowych oraz transkrypcje wywiadów zostały umieszczone w książce. Próba ilościowa w niniejszych badaniach wyniosła 2145 osób, zaś jej terytorialny zasięg obejmował całą Polskę, w tym 43 UTW. Na chwilę obecną badania Jaroszewskiej można uznać za najbardziej rozległe pod względem terytorialnym oraz liczebności próby w polskiej geragogice. Wyniki badań ilościowych zaprezentowano w 36 tabelach. Bogactwo zebranego materiału badawczego pozwoliło Jaroszewskiej na sformułowanie szeregu postulatów związanych z kolejno: czynnikami utrudniającymi realizację celów dydaktycznych, zadaniami lektora, charakterystyką międzykulturowego uczenia się, zestawieniem złożoności potrzeb i oczekiwań merytorycznych osób starszych wobec działań praktycznych (np. wykonywanych przez lektorów w UTW) oraz założeń dydaktycznych tworzących dydaktykę szczegółową.

Ostatni z rozdziałów książki jest swoistą metapolemiką z zaprezentowanymi wcześniej wynikami badań. Podsumowując publikację, Jaroszewska stawia szereg aktualnych pytań dla "glottogeragogiki”. Ponadto autorka podkreśla, że polski system kształcenia osób starszych w zakresie języków 
obcych charakteryzuje się: niewystarczającą liczbą publikacji poświęconych glottogeragogice, nieadekwatnymi metodami kształcenia seniorów, mało rozbudowanym zasobem pomocy dydaktycznych adresowanych do najstarszej grupy uczniów oraz ciągłym brakiem profesjonalnych kadr gerontologicznych specjalizujących się w językach obcych.

Warto podkreślić, że na polskim rynku wydawniczym istnieje wiele publikacji poświęconych: analizie rozwoju uniwersytetów trzeciego wieku, sposobom spędzania czasu wolnego przez osoby starsze, raportom dotyczącym kapitału ludzkiego najstarszej części społeczeństwa, lecz relatywnie mało do tej pory powstało publikacji związanych z podnoszeniem jakości kształcenia osób w wieku senioralnym. Publikacja Jaroszewskiej jest szczególnie ważna w kontekście wzmacniania intencjonalnego i profesjonalnego działania w instytucjach dedykowanych osobom starszym. Monografię w szczególności należy polecić dydaktykom języków obcych we wspomnianych wcześniej UTW. Ponadto publikacja powinna trafić także do innych osób odpowiedzialnych za kształtowanie jakości działań edukacyjnych adresowanych do seniorów, a więc: zarządów UTW, klubów seniora i kadr zarządzających projektami finansowanymi ze źródeł grantowych. Monografia jest także cennym źródłem informacji dla studentów kierunków społecznych. Zatem może służyć jako podstawowa literatura dla realizacji przedmiotów takich, jak: andragogika, gerontologia społeczna, geragogika i dydaktyka.

Recenzowana książka stanowi nowe podejście do procesu uczenia się i nauczania seniorów. Publikacja wyznacza kolejne obszary poszukiwań dla formującej się geragogiki. Niniejsza monografia może stanowić inspirację nie tylko dla lektorów i organizatorów kursów języka obcego dla seniorów, lecz również dla poznawania i prowadzenia badań w innych obszarach nauczania i uczenia, takich jak: nowe media, zajęcia ruchowe, artystyczne, psychologiczne i warsztaty manualne. 